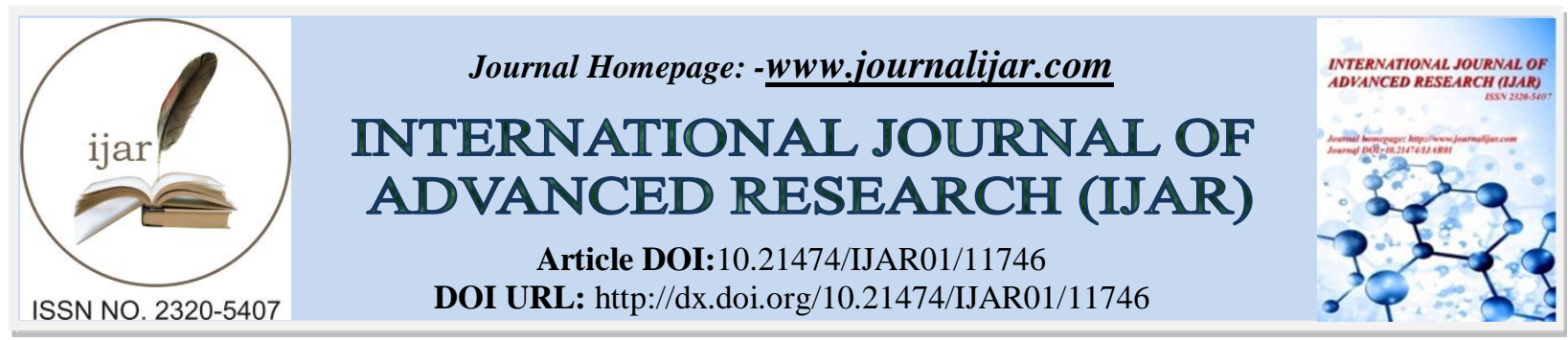

\title{
RESEARCH ARTICLE \\ UMBILICUS TROPAEOLIFOLIUS BOISS (CRASSULACEAE) A NEW RECORD TO THE FLORA OF THE ARABIAN PENINSULA
}

\author{
Abdul Wali A. Al-Khulaidi ${ }^{1,2}$, Ahmed Gushash ${ }^{3}$ and Awad A. Algarni ${ }^{1}$ \\ 1. Department of Biology, Faculty of Science and Arts, Albaha University, Baljurashi, KSA. \\ 2. Agricultural Research and Extension Authority, Taiz, Yemen. \\ 3. Department of Arabic Language, Faculty of Science and Arts, Albaha University, Baljurashi, KSA.
}

\section{Manuscript Info}

Manuscript History

Received: 20 July 2020

Final Accepted: 24 August 2020

Published: September 2020

Key words:-

New Plant Records, Flora of Saudi

Arabia, Arabian Peninsula, Umbilicus

\section{Abstract}

The plant diversity Sowth West of the Arabian Peninsula is considered to be very high due to its location, variation of climates, and geographical features. Generally, the Arabian Peninsula characterized by a very rich flora and is still not explored well. During the field survey of rare plant species, the authors collected a specimen of new taxa from the remote and inaccessible habitats in Jabal Ibrahim of the Asir region, Saudi Arabia. The plant was not reported so far in the flora of the Arabian Peninsula. The present paper deals with the record of one new plant species (Umbilicus tropaeolifolius Boiss) to the flora of Saudi Arabia and the Arabian Peninsula. The plant has a very small population range and very limited occupancy. The plant specimen was collected and later on identified and described with the available flora reference and with contact of a botanist.

Copy Right, IJAR, 2020,. All rights reserved.

\section{Introduction:-}

Jabal Ibrahim, also called Jabal Bather and Jabal Al-Abyad. It is a is a granite mountain within the Hijaz mountain range in southwestern Saudi Arabia, center of QureiBani Malik, and located $80 \mathrm{Km}$. NW al Baha city (Figure 1). That mountain is distinguished from other neighboring mountains by its high altitude, as its height is estimated at about 2,604 meters above sea level (Bird Life International, 2020).

Umbilicus is a genus of 10-12 species of flowering plants in the family Crassulaceae, it is perennial glabrous plant characterized by circular, succulent leaves, mostly with a tuberous or rhizome rootstocks (Hedberg, \& Edwards, 1989; Miller and Cope, 1996). The inflorescence is a long stem bearing many drooping tubular or bell-shaped flowers and most of the plants in this genus have peltate leaves except Umbilicus oppositifolius which has saxifragelike leaves (https://succulent-plant.com/families/crassulaceae/umbilicus.html).

The main distribution of Umbilicus tropaeolifolius is in Turkey (Rüstemoğlu and Beçet, 2015), Iran (Kanani, 2016; Veiskarami\&Sharifi-Tehrani, 2017) and Iraq (Hameed and Uzun, 2016; Key Biodiversity Survey of Iraq, 2010). In Flora of Somalia vol. 4: 277 (1995) and Vol 1, (1993), Thulin pointed out that the species also occurs between 1100 and $1500 \mathrm{~m}$ in northern Somalia and Sudan (Thulin, 2008). (Figure 1). There is also a very similar plant to $U$. tropaeolifolius named as U.paniculiformisWickens from the Red Sea Hills in Sudan (Wickens, 1997) and northern Eritrea (Hedberg, \& Edwards, 1989). 


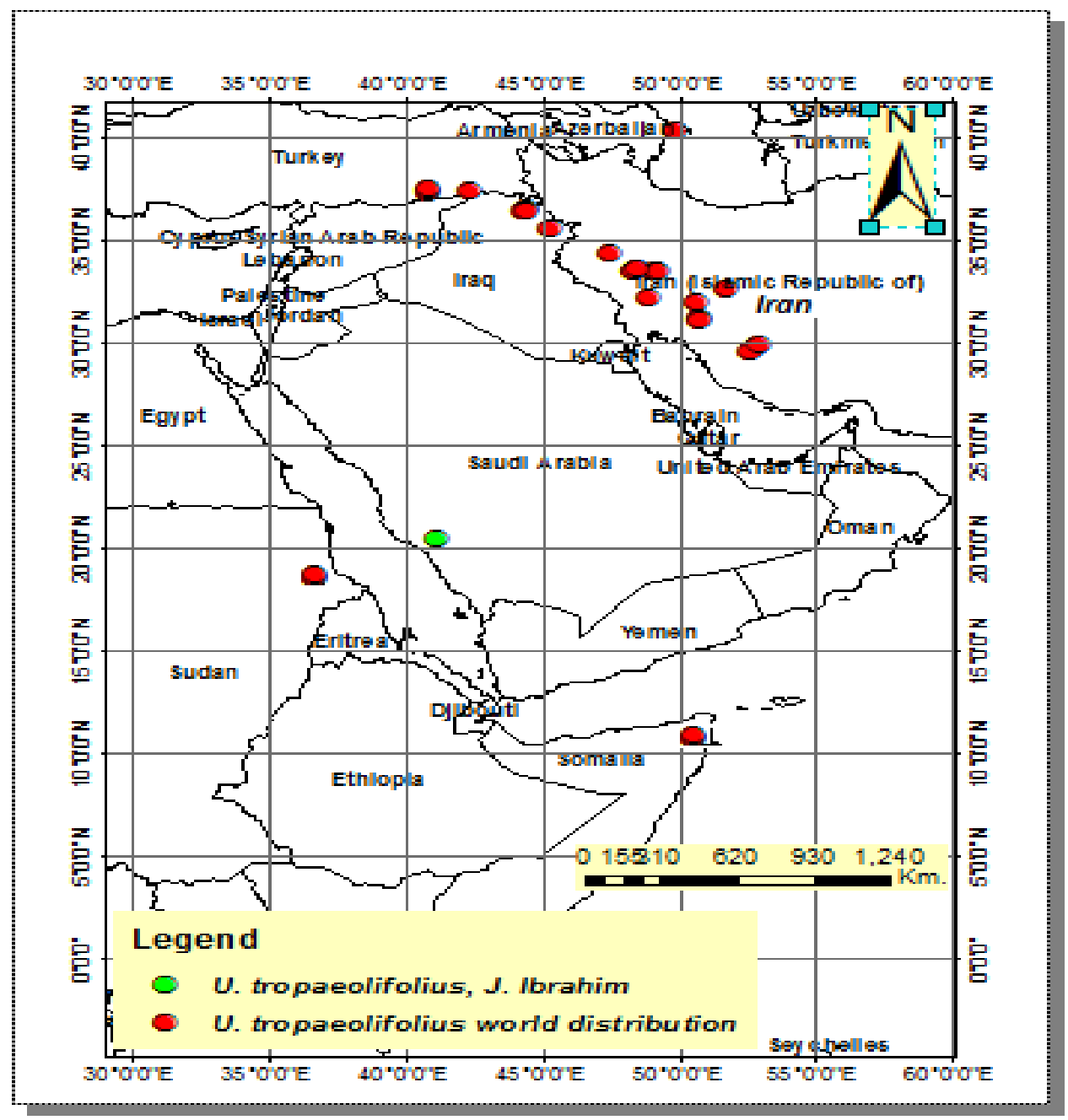

Figure 1:- The distribution of the plant in the world.

U.tropaeolifolius is considered as first record from the Arabian Peninsula, although the occurrence is fairly close to the localities in Sudan across the Red Sea (Thulin, 2008). Two plant species of Umbilicus, U. rupestris (Salisb.) Dandy and $U$. horizontalis (Guss.) DC. with 2 varaities (var horizontalisand var. intermedius) were recorded from Arabian Peninsula, mainly between 1000 and 2950m, (Wood, 1977; Miller and Cope,1996; Collenette, 1999; and Al-Khulaidi, 2013). U. horizontalis var. intermedius(Boiss.) D.F.Chamb. consideredinKew science resourceas as a synonyme of U.intermedius Boiss (https://www.ipni.org/n/276961-1), which raised the Umbilicus species in Arabian Peninsula including U.tropaeolifoliusto four species.

The present paper deals with a morphological description and geographical distribution of unknown and new plant species. The aim of the study is to add a new plant that has not been previously recordedto the Saudi Arabian's and Arabian Peninsula's plants.

\section{The location area:}

:U.tropaeolifolius is found at Jabal Ibrahim, Asir region, $75 \mathrm{Km}$. NW al Baha city, Saudi Arabia

\section{Materials and Methods:-}

Several visits were made in the Asir region for the rare plant species survey during 2019 in different seasons. Unknown plants was found inside a cave, in Jabal Ibrahim, Asir region. The identification and description of collected plant samples have been done with the relevant literature (Wickens, G. E. (1997: Thulin, 2008; Hedberg, 
\& Edwards, 1989). The plant has been sufficiently dried, pressed and reserved in the Herbarium of Al-Baha University, Saudi Arabia. Under: Al-Khulaidi; 9-2020

\section{Result and Discussion:-}

UmbilicustropaeolifoliusBoiss, Diagn. Pl. Orient. ser. 1, 3: 14 (1843). (Crassulaceae ):

\section{Synonyms:}

Cotyledontropaeolifolia Bornm., Beih. Bot. Centralbl., Abt. 2. 32(2): 389 (1914).

Umbilicusoxypetalus Boiss., Diagn. Pl. Orient. ser. 1, 3: 15 (1843).

Specimen: Jabal Ibrahim, Asir region, $75 \mathrm{Km}$. NW al Baha city, Saudi Arabia.

\section{Description:}

An erect or procumbent perennial herb. The stem up to $30 \mathrm{~cm}$ tall. leaves orbicular -peltate; petiole up to $6.5 \mathrm{~cm}$ long; Cauline leaves alternate and smaller than basal leaves, blade from 2 to $5 \mathrm{~cm}$ in diameter, irregularly crenatelobbed margin. Inflorescence terminal, in panicle, erect to sub erect, up to $15 \mathrm{~cm}$ high, sparsely branched, bearing many bell-shaped, white flowers, pedicle 2-3 cm. Calyx-lobes lanceolate, 2-3 mm long. Petals white 5-parted, campanulate, up to $5 \mathrm{~mm}$ long, 5 carpels up to $5 \mathrm{~mm}$ and 10 stamens.
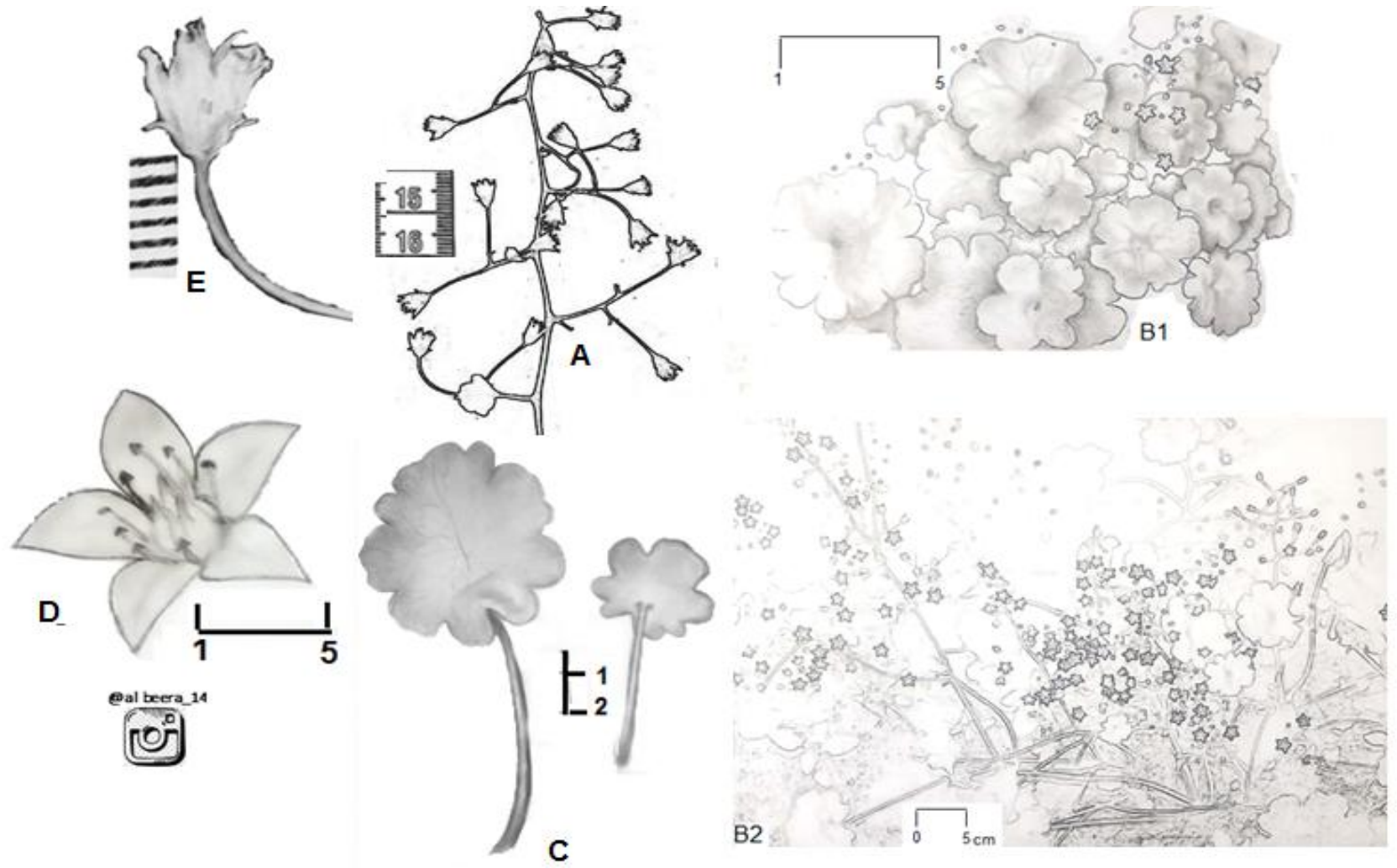

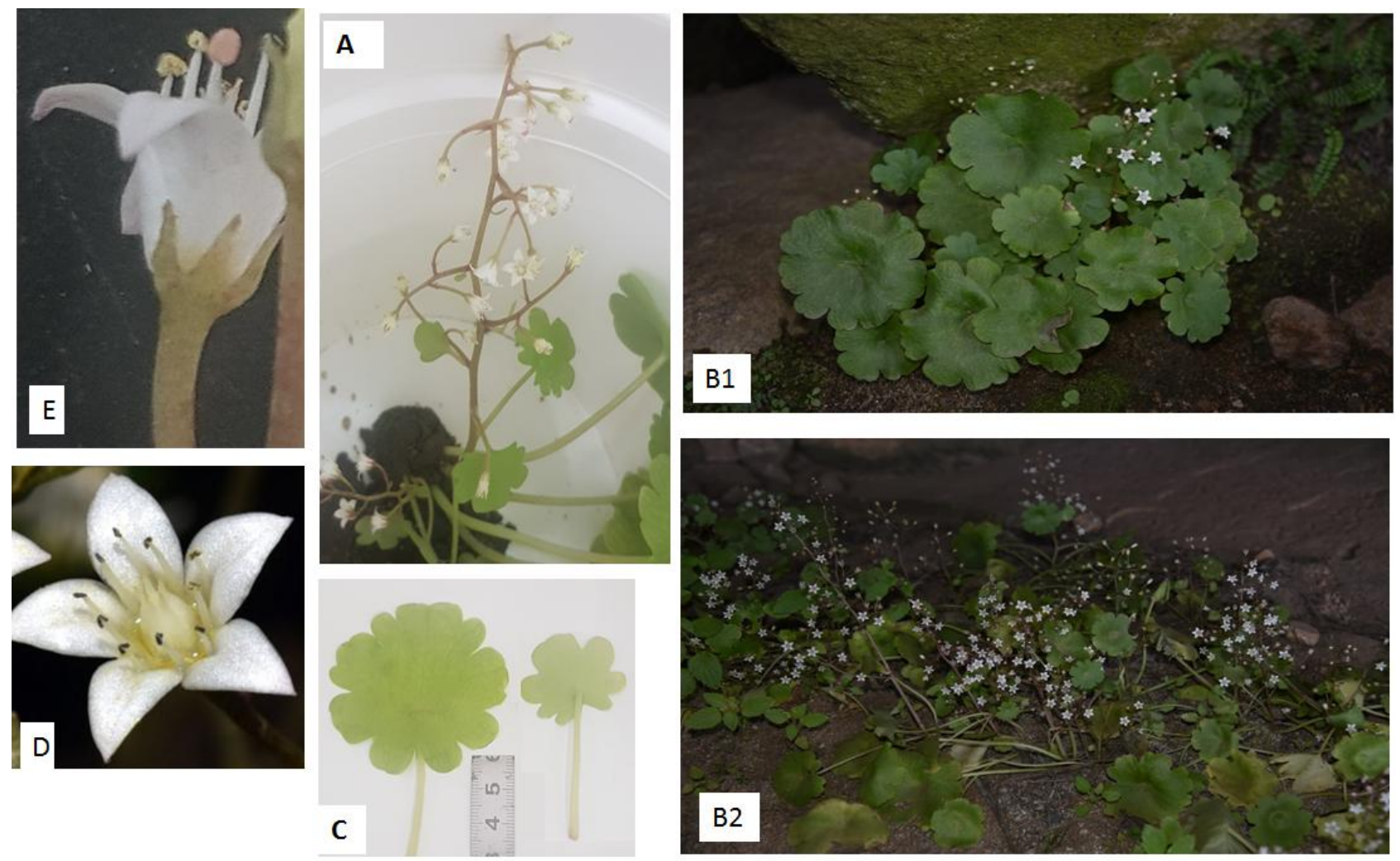

Figure 2:- Umbilicustropaeolifolius. A. inflorescence; B1\&2. Habit; C. leaf' D. opened flower with 5 carpels and 10 stamens; E. flower showing the calyx. Drown by Miss. Abeer Abdul Jalil.

\section{Discussion:-}

A large number of palaeotropical taxa belong to the Afromontane element are found in JibalAssurat including Jabal Ibrahim, these plant species may arrived by migration from the East African mountain chains c. 15-35 million years ago (Kürschner, 2008). It is expected with the extra exploring of the vegetation and the flora of the region to discover new plants not previously recorded and additions to Flora of the Saudi Arabia and Arabian Peninsula, as well as to the Flora of Arabian Peninsula.

U.tropaeolifolius and $U$. paniculiformisfrom Sudan, distinguished from other members of the genus by the distinctive paniculate inflorescence (Wickens, 1997; Eggli, 2003) and deeply divided corolla (Hedberg, \& Edwards, 1989). The different between the two species suggested to be the pedicel length, the pedicel in $U$. paniculiformisranges between 2-6 mm (Wickens, 1997), while in U.tropaeolifolius ranges between 2-3 cm. Molecular study is recommended to make sure that the two plants being different or the same.

\section{Acknowledgment:-}

We extend our thanks and appreciation to plant scientists Prof. Mats Thulin (Uppsala University, Sweden) and Prof. Norbert Kilian from FreieUniversität Berlin for their involvements and discussions on naming and defining the plant.

\section{References:-}

1. Al-Khulaidi, A. (2013). Flora of Yemen. The Sustainable Natural Resource, Management Project (SNRMP II), EPA and UNDP, Republic of Yemen; http://ye.chm-cbd.net/implementation/documents/1-flora-final-by-dr.abdul-wali-al-khulaidi-2013-part-1-introduction.pdf

2. Collenette, S. (1999). Wildflowers of Saudi Arabia. Riyadh, Saudi Arabia: National Commission for Wildlife Conservation and Development (NCWCD); https://www.worldcat.org/title/wildflowers-of-saudiarabia/oclc/42968766 
3. Bird Life International (2020) Important Bird Areas factsheet: WadiTurabah and Jabal Ibrahim; http://datazone.birdlife.org/site/factsheet/wadi-turabah-and-jabal-ibrahim-iba-saudi-arabia

4. Eggli, U (ed.) ( 2003 ). Illustrated Handbook of Succulent Plants: Crassulaceae, Springer Science \& Business Media, Muh. 22, 1434 AH - Science - 506 pages; https://www.springer.com/gp/book/9783540419655

5. Hameed, M.A., Uzun, A., Saeed. J.F. (2016). Vascular Plant Taxa of Hujran Basin, Erbil, Iraq. KSU J. Nat. Sci., $\quad$ 19(3): 279-295, 2016; https://www.researchgate.net/publication/309764009_Vascular_Plant_Taxa_of_Hujran_Basin_Erbil_Iraq

6. Hedberg, I. \& Edwards, S. (eds) (1989). Flora of Ethiopia vol. 3, Pittosporaceae to Araliaceae. The National Herbarium, Biology Department, Science faculty, Addis Ababa univ. Ethiopia and the department of systematic, Sweden. Pp.660; https://www.worldcat.org/title/flora-of-ethiopia-and-eritrea-vol-3-pittosporaceaeto-araliaceae/oclc/185579854

7. Kanani, M.R. (2016). Conservation and ecological assessment of plants in Bamou National Park, Iran. Environmental Sciences. 14(3), 173-186; https://www.sid.ir/en/journal/ViewPaper.aspx?id=608588

8. Key Biodiversity Survey of Iraq (2010). Site Review. Nature Iraq \& the Iraq Ministry of Environment Sulaimani, Kurdistan, Iraq; http://ar.natureiraq.org/uploads/9/2/7/0/9270858/_kba_2011_site_review_-_ni0311-01p.pdf

9. Kürschner, H. (2008). Biogeography of South-West Asian Bryophytes - With Special Emphasis on the Tropical Element. Turk J Bot 32 (2008) 433-446; https://dergipark.org.tr/en/pub/tbtkbotany/issue/11801/141085

10. Miller, A.G. and Cope, T.A. (1996). Flora of the Arabian Peninsula and Socotra, Vol. 1. Edinburgh University press in Association of Royal Botanic Garden, Edinburgh \& Kew, UK; https://www.amazon.com/FloraArabian-Peninsula-Socotra-Vol/dp/0748604758

11. Rüstemoğlu, M. and Beçet, L. (2015). The flora of Mezraa/Turkey district and its surroundings 2. Biological $\begin{array}{lllll}\text { Diversity and } & \text { Conservation. } & 8 / 3 & \text { (2015) }\end{array}$ https://www.researchgate.net/publication/310367188_The_flora_of_MezraaTurkey_district_and_its_surroundin gs

12. Thulin, M. (2008). Flora Somalia, Vol 1, (1993) Author: by [updated by M. Thulin 2008; https://plants.jstor.org/compilation/Umbilicus.tropaeolifolius

13. Wickens, G.E. (1997). A New Species of Umbilicus (Crassulaceae) from the Sudan Republic. Kew Bulletin, Vol. 33, No. 3 (1979), pp. 421-422; https://www.jstor.org/stable/4110142

14. Wood, J.R.I. (1997). A Handbook of the Yemen Flora. Kew: Royal Botanic Gardens KEW, United Kingdom; https://www.worldcat.org/title/handbook-of-the-yemen-flora/oclc/60140659

15. Veiskarami, G.H. and Sharifi-Tehrani, M. (2017). Plant species diversity in the Central Zagros Region of Iran. PHYTOLOGIA BALCANICA 23(1): 101-118 Sofia, 2017; https://www.semanticscholar.org/paper/Plantspecies-diversity-in-the-Central-Zagros-of-Veiskarami-SharifiTehrani/1b5603a5ffc47ae75f37c9106a3a79a28d8777c7?p2df. 